\title{
PHYSICAL PROPERTIES AND PRESERVATIVE TREATMENT OF EUCALYPTUS AND CORYMBIA WOOD
}

\author{
Manolo Trindade Quintilhan ${ }^{1 *}$, Weslley Candido de Oliveira ${ }^{2}$, Aylson Costa Oliveira ${ }^{3}$, Bárbara Luísa Corradi \\ Pereira ${ }^{4}$, Romulo Môra ${ }^{5}$ \\ 1*Universidade Estadual de Campinas, Programa de Pós-Graduação em Ecologia, Campinas, São Paulo, Brasil - \\ manolo_trindade@yahoo.com.br \\ ${ }^{2}$ Universidade Federal de Mato Grosso, Programa de Pós-Graduação em Ecologia, Cuiabá, Mato Grosso, Brasil - wcoflorestal@ gmail.com \\ ${ }^{3}$ Universidade Federal de Mato Grosso, Departamento de Engenharia Florestal, Cuiabá, Mato Grosso, Brasil - aylsoncosta@ gmail.com; \\ ${ }^{4}$ babicorradi@gmail.com; ${ }^{5}$ romulomef@yahoo.com.br.
}

Received for publication: 01/10/2019 - Accepted for publication: 16/12/2019

\begin{abstract}
Resumo
Propriedades físicas e tratamento preservativo da madeira de Eucalyptus e Corymbia. As propriedades da madeira influenciam seu uso como produto final, sendo assim, é essencial conhecer sua relação e influência na qualidade da preservação. Nesse sentido, para o presente estudo, objetivamos determinar as propriedades físicas de Corymbia citriodora [Eucalyptus citriodora Hook]; Eucalyptus camaldulensis Dehnh. e Eucalyptus camaldulensis Dehn. $\mathrm{x}$ Eucalyptus grandis e a qualidade do tratamento preservativo com CCA-C em autoclave. Determinamos o diâmetro, as porcentagens de cerne e alburno e sua relação, e também a densidade básica dos três materiais genéticos. A qualidade da preservação foi avaliada por meio da área tratada e não tratada por CCA, além de sua penetração e retenção. A maior proporção de alburno, área tratada e maior valor de densidade foi encontrada em C. citriodora, enquanto o híbrido E. camaldulensis x E. grandis apresentou o maior nível de retenção de CCA. O diâmetro e a densidade apresentaram a maior correlação com a retenção de CCA na madeira, o comprimento e a umidade dos toretes também apresentaram influência. Todos os clones apresentaram qualidade de tratamento químico satisfatória para uso como mourões de cerca.

Palavras-chave: Qualidade da madeira, Preservação química da madeira, CCA.
\end{abstract}

\section{Abstract}

The properties of wood influence its use as a final product, so it is essential to know their relation and influence on the quality of preservation. In this sense, for the present study we aim at the determination of the physical properties of Corymbia citriodora [Eucalyptus citriodora Hook]; Eucalyptus camaldulensis Dehnh. and Eucalyptus camaldulensis Dehn. $\mathrm{x}$ Eucalyptus grandis, and the quality of the preservative treatment with CCA$\mathrm{C}$ in an autoclave. We determined diameter, heartwood and sapwood percentages, and their relationship, as well as the basic density for the three genetic materials. The quality of the preservation was evaluated through the area treated and not treated by CCA, besides its penetration and retention. The highest proportion of sapwood, treated area, and highest density value was found in C. citriodora, whereas the hybrid $E$. camaldulensis x E. grandis presented the highest level of CCA retention. The diameter and density showed the highest correlation with CCA retention in wood, the length and moisture of the small logs also shown to be influential. All clones presented satisfactory chemical treatment quality for use as fence posts.

Keywords: Wood quality, Chemical wood preservation, CCA.

\section{INTRODUCTION}

Wood is an organic material, heterogeneous and highly variable in its properties and characteristics. This wide variability allows the use of wood in several ways, making it a fundamental material (OLIVEIRA et al. 2005). Actually, the most used wood in the global industry are those of Eucalyptus and Corymbia species (FAO, 2006). This is due to the characteristics of their trees and plantations, which present rapid growth, high ecological plasticity and broad industrial use (FERREIRA et al., 2017). In this way it is the most planted forest genera in the world and in Brazil, having occupied in 2016 more than 5.7 million hectares, $91 \%$ of the country's tree plantations (IBÁ, 2017).

Eucalyptus genera presents more than 800 species, besides several varieties and genetic crosses (BALDIN et al., 2017), resulting in a high variability of wood properties (LIMA et al., 2014). In view of the great heterogeneity of wood properties, which vary from family to different regions of the same tree its characterization is fundamental to its proper use (OLIVEIRA et al. 2005). Considering the different sectors of the forest industry and their demand for materials of specific composition, a distinction and categorization of the wood properties is necessary.

The lack of knowledge about the properties of the main raw material of the Brazilian treated wood sector caused its production to be minimal when compared to other areas (VIDAL et al., 2015). Currently, eucalyptus

FLORESTA, Curitiba, PR, v. 51, n. 2, p. 410-418, abril/jun 2021.

Quintilhan, M. T. et.al.

ISSN eletrônico 1982-4688

DOI: 10.5380/rf.v51 i2. 69280 
wood is responsible for $93.5 \%$ of the material used in the production of this sector (IBGE, 2017). Thus, more studies are needed, considering the properties of its wood (ARANTES et al., 2017), the quality of its preservation (PAES et al., 2012) and different potential species (RADIVOJEVIC; COOPER, 2010). This gap resulted in a production of low value-added products, where approximately $60 \%$ is destined for fence posts, $30 \%$ for posts, $5 \%$ for sleepers and only $5 \%$ for civil construction (IBGE, 2017).

Eucalyptus treated wood for being mainly used as fence posts is used in under adverse conditions, such as direct contact with the ground (QUINTILHAN et al., 2018). Eucalypt woods commonly do not exhibit high natural durability, nevertheless, when properly treated the wood of these species can achieve high durability, for periods up to 50 years (PAES et al. 2012). Among the treatments used for wood preservation, the full-cell (Bethell), vacuum-pressure, which mainly uses the water-soluble preservative Cromated Copper Arsenate (CCA), is the most used, given its greater scale of production and efficiency (VIDAL et al., 2015).

Preservation quality control and use classification of treated wood is obtained by the degree of distribution, penetration and retention of CCA in the wood, where the values are found in the norms, NBR 9480 (ABNT, 2009) and NBR 6232 (ABNT, 2013). The quality of the preservation is aided by the control of the treatment stages, besides the use of materials that present wood technological properties that favour an adequate chemical treatment (LOPES et al., 2017). Properties such as log diameter, moisture content, heartwood and sapwood ratio, and wood density are essential, since they are associated with wood quality and its other characteristics (PEREIRA et al., 2013; AMARAL et al. 2014; ARANTES et al., 2017).

Studies that indicate which species have the greatest potential for preservation and which wood properties have the greatest relationship with a high quality treated wood are fundamental. Advances in this way should generate key information that will aid in the development of the treated wood sector. In this sense, in the present study we aim the determination of physical properties of Corymbia citriodora [Eucalyptus citriodora Hook]; Eucalyptus camaldulensis Dehnh. and Eucalyptus camaldulensis Dehnh. X Eucalyptus grandis, and the evaluation of the quality of preservative treatment with CCA-C in an autoclave.

\section{MATERIAL AND METHODS}

\section{Area}

The wood used for the present study was obtained from a eucalyptus plantation under a spacing of $3 \times 3 \mathrm{~m}$ located on Santo André Farm, Chapada dos Guimarães, Mato Grosso, Brazil (1508' 05" S, 55 59' 10" W, at 368 $\mathrm{m}$ altitude). The average annual temperature is $21^{\circ} \mathrm{C}$ and the average annual rainfall is $1480 \mathrm{~mm}$ (Brasil, 1982). The climate, according to Köpen classification, is Aw type, with predominance of wet summer and a dry winter period with lower temperatures and lower rainfall. The predominant soil is classified as dystrophic algal quartz sand.

Corymbia citriodora [Eucalyptus citriodora Hook]; Eucalyptus camaldulensis Dehnh.; and the hybrid Eucalyptus camaldulensis Dehnh. x Eucalyptus grandis Hill (Hybrid 1277) were selected and sampled due to the wide use in the region and in the treated wood sector. For each clone, eight small logs (four per tree) with $40 \mathrm{~cm}$ in height were sampled from the basal area of the tree, of which four per clone were selected for preservative treatment. To evaluate the wood properties, six $5 \mathrm{~cm}$ long discs were collected, in the same region of the tree.

\section{Determination of heartwood and sapwood}

The mean discs diameter was initially determined per clone. The discs were initially sanded to assess the proportions of heartwood and sapwood. Changes in color and the occurrence of pores obstructed by tyloses marked the heartwood region. A 10x magnifying glass lens was used to detect such characteristics. From one end to the other of each disc, two perpendicular straight lines were drawn through the center of the pith. Measurements of total diameter and heartwood diameter were made with a precision ruler equal to $10 \mathrm{~mm}$ and the percentages of heartwood and sapwood and their relationship (Equation 1) were calculated.

$$
H / S=\frac{D h^{2}}{D^{2}-D h^{2}}
$$

Being:

$\mathrm{H} / \mathrm{S}=$ heartwood / sapwood ratio;

$\mathrm{Dh}=$ heartwood diameter, in $\mathrm{cm}$;

$\mathrm{D}=$ diameter of the disc without bark, in $\mathrm{cm}$. 


\section{Basic density}

To measure the basic density, four discs were selected from each tree, and two opposite wedges were removed from each disc. The hydrostatic balance method was used to determine the basic density fulfilling the specifications contained in standard NBR 11941 (ABNT, 2003). The procedure consisted of 5 steps:

1) The wood discs were submerged in water for a period of 2 weeks, until the wood was completely saturated.

2) The saturated volume was determined by means of an analytical balance by immersing the discs attached to a rod until complete submersion

3) The wood discs were dried in an oven $\left(105 \pm 2{ }^{\circ} \mathrm{C}\right)$ for 24 hours until constant mass.

4) Measurement of the dry mass of the discs was again performed on the analytical balance.

5) The basic density of the wood was calculated.

\section{Preservative treatment}

The small logs selected for wood preservation were manually peeled and submitted to natural drying until reaching a moisture content $(\sim 12 \%)$, determined by means of a resistive type electric moisture meter (measurement in the central region of the log, perpendicular to the fibers, $5 \mathrm{~cm}$ long pin), and then subjected to the preservative treatment.

The preservative treatment was performed in an industrial autoclave, with dimensions of $13 \mathrm{~m}$ long x 1.80 $\mathrm{m}$ in diameter. The treatment was carried out by the full-cell method (Bethell), with $2 \%$ of active ingredients of Cromated Copper Arsenate (CCA type C) seeking to achieve a minimum retention value of $6.5 \mathrm{~kg} . \mathrm{m}^{-3}$ as determined to NBR 9480 (ABNT, 2009).

The steps of the process involved (i) loading the wood into the autoclave cylinder, (ii) applying initial vacuum to $560 \mathrm{mmHg}$ for 30 minutes, (iii) filling with the preservative solution, (iv) applying $12 \mathrm{kgf} / \mathrm{cm}^{2}$ pressure for 90 minutes, (v) removal of the product from the cylinder, final vacuum at $560 \mathrm{mmHg}$ for $10 \mathrm{minutes}$, and (vi) unloading, according to Figure 1. After the preservative treatment, the wood was stored in a place protected from humidity and without ground contact.

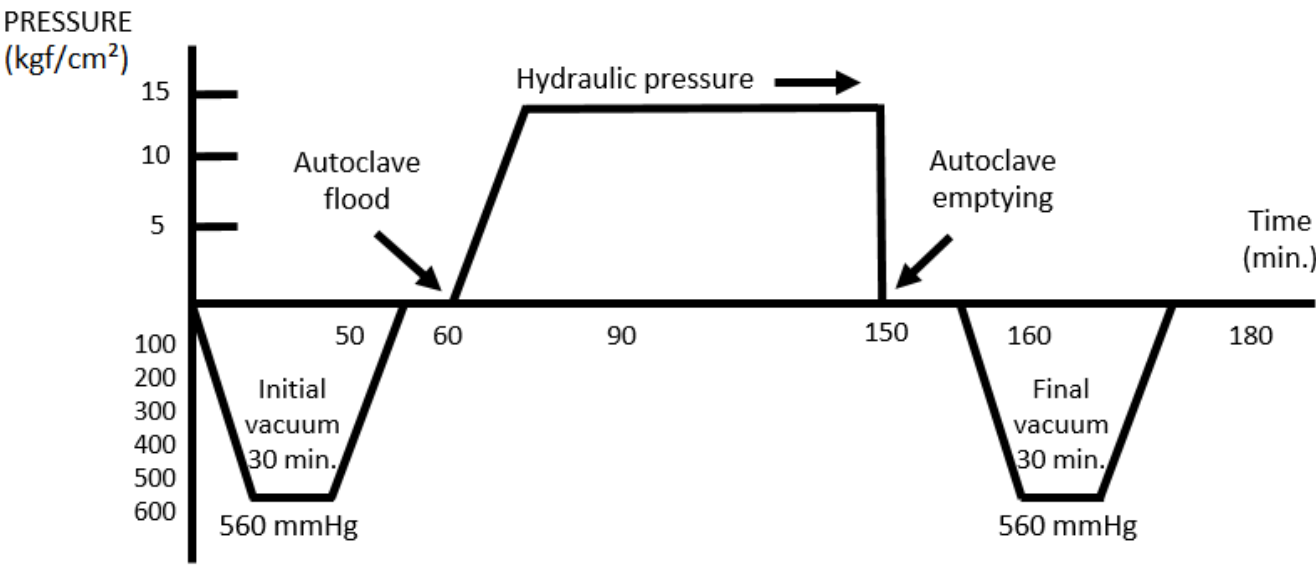

Figure 1. Graphic representation of the preservative treatment of small eucalyptus logs (Bethell method), adapted from Sales-Campos et al., (2003).

Figura 1. Representação gráfico do tratamento preservative de toretes de eucalipto (método Bethell), adaptado de Sales-Campos et al., (2003).

\section{Quality of preservative treatment}

The preservative treatment was evaluated by the application of chrome azurol $\mathrm{S}$ on the entire cross section of the small logs, with the aid of a brush. The chrome of the solution reacts with the copper of the CCA, causing the wood to acquire a dark blue coloration (Figure 2A). The absence of copper in the wood, in turn, results in a pink coloration. The qualitative evaluation of the CCA penetration was made from the identification of the distribution of the preservative solution in the sapwood, being classified as: null; vascular; partial irregular; peripheral partial and full (SALES-CAMPOS et al., 2003), according to Figure 2B. 

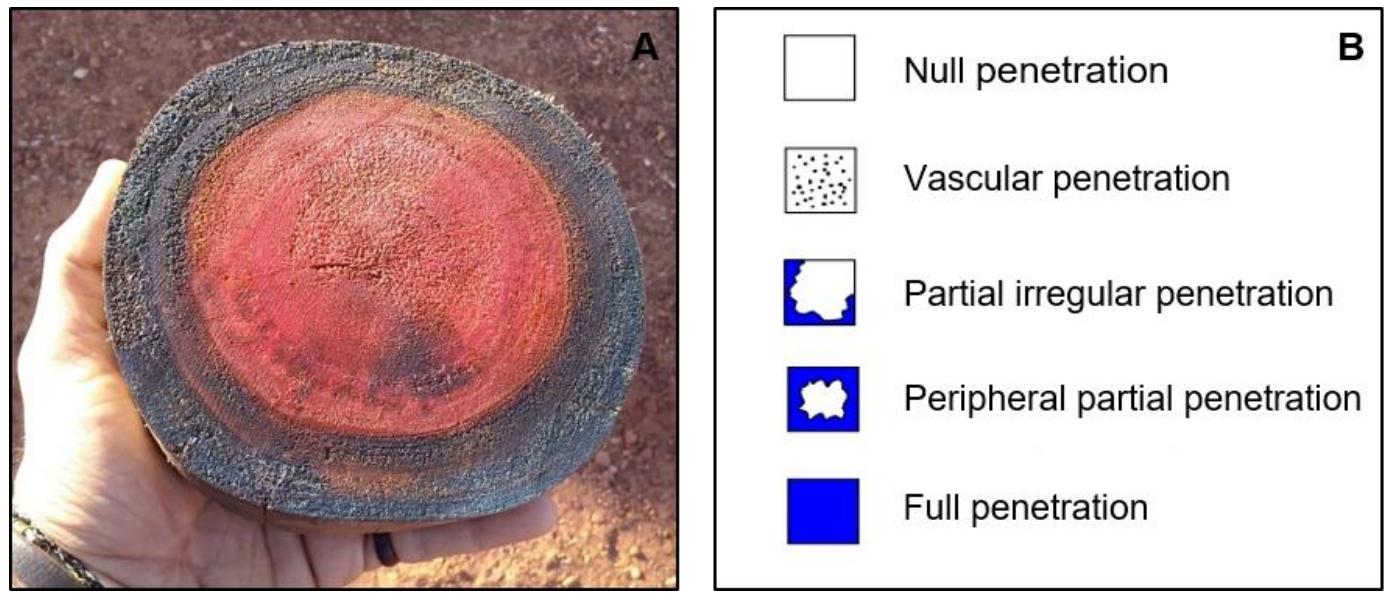

Figure 2. A - Reaction of chrome azurol S with copper penetrated into wood. B - Classification of CCA penetration, adapted from Sales-Campos et al. (2003)

Figura 2. A - Reação do cromoazurol-S com o cobre penetrado na madeira. B - Classificação da penetração do CCA, adaptado de Sales-Campos et al. (2003).

The penetration of the product into the wood was also evaluated by area, through observation of the cross section of the small logs, before and after chemical treatment. For this, the penetration of the product, indicated by the chrome azurol S reaction, was measured. The measurements were carried out with the aid of a ruler with precision of $1.0 \mathrm{~mm}$, used in the measurements of the average penetration of the product in the cross section and in the area treated in the wood.

After treatment and primary fixation of CCA in the wood, its retention was determined by five wood cores sampled in the central region of the length of the sticks. Only the region treated by preservative (sapwood, green color) was analyzed. The heartwood for this evaluation has been separated and discarded. For this purpose, an extraction drill was used, with dimensions of $53 \mathrm{~mm}$ in length and internal diameter of $13 \mathrm{~mm}$.

This was done to determine the air-dry density of the treated portion of the wood. The sampled material was then minced in a Willey-type mill and passed through at 35 mesh sieve, and sequentially oven dried at $103 \pm$ $2^{\circ} \mathrm{C}$ for about 2 hours. Afterwards the material was stored in Myler bottom $2.5 \mathrm{~cm}$ diameter plastic cuvettes and covered with parafilm plastic in order to analyze the CCA retention (Equation 2). The sum of copper, chrome and arsenic contents expressed in $\mathrm{kg} \cdot \mathrm{m}^{-3}$ was determined by means of an X-ray spectrometer.

$$
R=C E * D * 10
$$

Where:

$\mathrm{R}=$ retention, in $\mathrm{kg} \cdot \mathrm{m}^{-3}$

$\mathrm{CE}=$ reading of the chemical element in the spectrometer

$\mathrm{D}=$ density of the baguette, in $\mathrm{g} \cdot \mathrm{cm}^{-3}$

\section{Statistical analysis}

The results obtained from wood properties (diameter, density, heartwood and sapwood area) as well as the preservative treatment quality (treated and untreated area and retention of CCA) of the three genetic materials were submitted for analysis of variance - ANOVA to verify significant differences. When significant differences were established, the Tukey test was applied at 95\% level of significance. For further investigation, Pearson's correlation was used, observing the level (95 and 99\%) and the direction of the relation (positive, negative or absent) of the wood properties with the qualitative parameters of preservation.

\section{RESULTS}

\section{Properties of wood and preservative treatment quality}

The values of the physical properties and percentage of area treated and not treated for three genetic material are found in Table 1. The smaller diameter was observed in C. citriodora, with a value of $12.6 \mathrm{~cm}$, being $14.13 \%$ lower than E. camaldulensis and 33.02\% lower than E. camaldulensis x E. grandis (Table 1). The highest percentage of sapwood was found in C. citriodora $(76.47 \%), 31.82 \%$ higher than E. camaldulensis $\mathrm{x}$ E. grandis and $42.62 \%$ higher than $E$. camaldulensis (Table 1). The highest percentage of treated area was observed in $C$. citriodora $(86.61 \%)$, being $56.16 \%$ higher than E. camaldulensis and $55.09 \%$ than E. camaldulensis $\mathrm{x}$ E. grandis.

FLORESTA, Curitiba, PR, v. 51, n. 2, p. 410-418, abril/jun 2021. 
The highest heartwood value was found in E. camaldulensis clone (56.11\%), being $14.72 \%$ higher than E. camaldulensis x E. grandis and $58.1 \%$ higher than $C$. citriodora. The relationship between the heartwood and sapwood $(\mathrm{H} / \mathrm{S})$ for the three evaluated genetic materials is also observed in Table 1 . The E. camaldulensis clone presented the highest ratio (1.22), with the E. camaldulensis x E. grandis intermediate value (0.93), whereas $C$. citriodora presented 0.22. For E. camaldulensis, Pereira et al. (2013) observed similar values for this same relationship.

The mean basic wood density values also differed among genetic materials (Table 1). The clone with the highest density determined was $C$. citriodora $\left(0.717\right.$ g.cm $\left.{ }^{-3}\right)$, being $16.45 \%$ higher than that observed for $E$. camaldulensis and $33.61 \%$ higher than the E. camaldulensis x E. grandis hybrid. Similar values of density were observed by Oliveira et al. (2005) for C. citriodora and E. camaldulensis, respectively.

Table 1. Mean values of diameter $(\mathrm{cm})$, percentage of sapwood $(\%)$, treated area $(\%)$, heartwood $(\%)$ and untreated area $(\%)$, heartwood/sapwood ratio $(\mathrm{H} / \mathrm{S})$ and basic density $\left(\mathrm{g} \cdot \mathrm{cm}^{-3}\right)$ of evaluated genetic materials.

Tabela 1. Valores médio de diâmetro $(\mathrm{cm})$, porcentagem de alburno (\%), área tratada (\%), cerne (\%) e área não tratada $(\%)$, relação cerne/alburno $(\mathrm{H} / \mathrm{S})$ e densidade básica $\left(\mathrm{g} \cdot \mathrm{cm}^{-3}\right)$ dos materiais genéticos avaliados.

\begin{tabular}{cccccccc}
\hline Genetic Material & Diameter & $\mathrm{S}$ & $\begin{array}{c}\text { Treated } \\
\text { Area }\end{array}$ & $\mathrm{H}$ & $\begin{array}{c}\text { Untreated } \\
\text { Area }\end{array}$ & $\mathrm{H} / \mathrm{S}$ & Density \\
\hline $\begin{array}{c}\text { Corymbia } \\
\text { citriodora }\end{array}$ & $12.6 \mathbf{c}$ & $76.47 \mathbf{a}$ & $86.61 \mathbf{a}$ & $23.52 \mathbf{b}$ & $13.38 \mathbf{b}$ & $0.26 \mathbf{b}$ & $0.717 \mathbf{a}$ \\
$\begin{array}{c}\text { Eucalyptus } \\
\text { camaldulensis }\end{array}$ & $14.38 \mathbf{b}$ & $43.88 \mathbf{b}$ & $48.64 \mathbf{b}$ & $56.11 \mathbf{a}$ & $51.35 \mathbf{a}$ & $1.22 \mathbf{a}$ & $0.599 \mathbf{b}$ \\
$\begin{array}{c}\text { E. camaldulensis } \\
\text { x E. grandis }\end{array}$ & $16.76 \mathbf{a}$ & $52.14 \mathbf{b}$ & $47.71 \mathbf{b}$ & $47.85 \mathbf{a}$ & $52.28 \mathbf{a}$ & $0.93 \mathbf{a}$ & $0.476 \mathbf{c}$ \\
\hline
\end{tabular}

Means, followed vertically by the same letter, do not differ statistically from each other (Tukey’s test, p<0.05).

The retention of chromium $\left(\mathrm{CrO}_{3}\right)$, copper $(\mathrm{CuO})$, arsenic $\left(\mathrm{As}_{2} \mathrm{O}_{5}\right)$ and their combination $(\mathrm{CCA}-\mathrm{C})$ in the wood, showed differences between the genetic material (Figure 3). The mean value of chromated copper arsenate retention (CCA-C) was higher in the hybrid E. grandis $\mathrm{x}$ E. camaldulensis $\left(16.3 \mathrm{~kg} \cdot \mathrm{m}^{-3}\right)$ (Figure 3). The retention in the wood of the remaining clones was similar among them, being approximately $24.25 \%$ lower than in the hybrid. The retention values obtained for the different genetic materials were similar to those of Paes et al. (2012), who evaluated the CCA-C retention in treated eucalyptus logs, mainly in the external region of the cross section, where the retention was higher.

The individual retention of chromium was higher for $E$. grandis $\mathrm{x}$ E. camaldulensis hybrid $\left(7.1 \mathrm{~kg} \mathrm{~m}^{-3}\right)$ being $25.35 \%$ higher than in C. citriodora and $21.13 \%$ in E. camaldulensis, these being similar. For copper, the retention among the clones was similar, varying between 2.8 and $3.5 \mathrm{~kg} \cdot \mathrm{m}^{-3}$. Arsenic retention was higher in $E$. camaldulensis $\mathrm{x}$ E. grandis $\left(5.7 \mathrm{~kg} . \mathrm{m}^{-3}\right)$ than in the E. camaldulensis and C. citriodora wood $(33.33 \%$ and $26.32 \%)$, respectively.

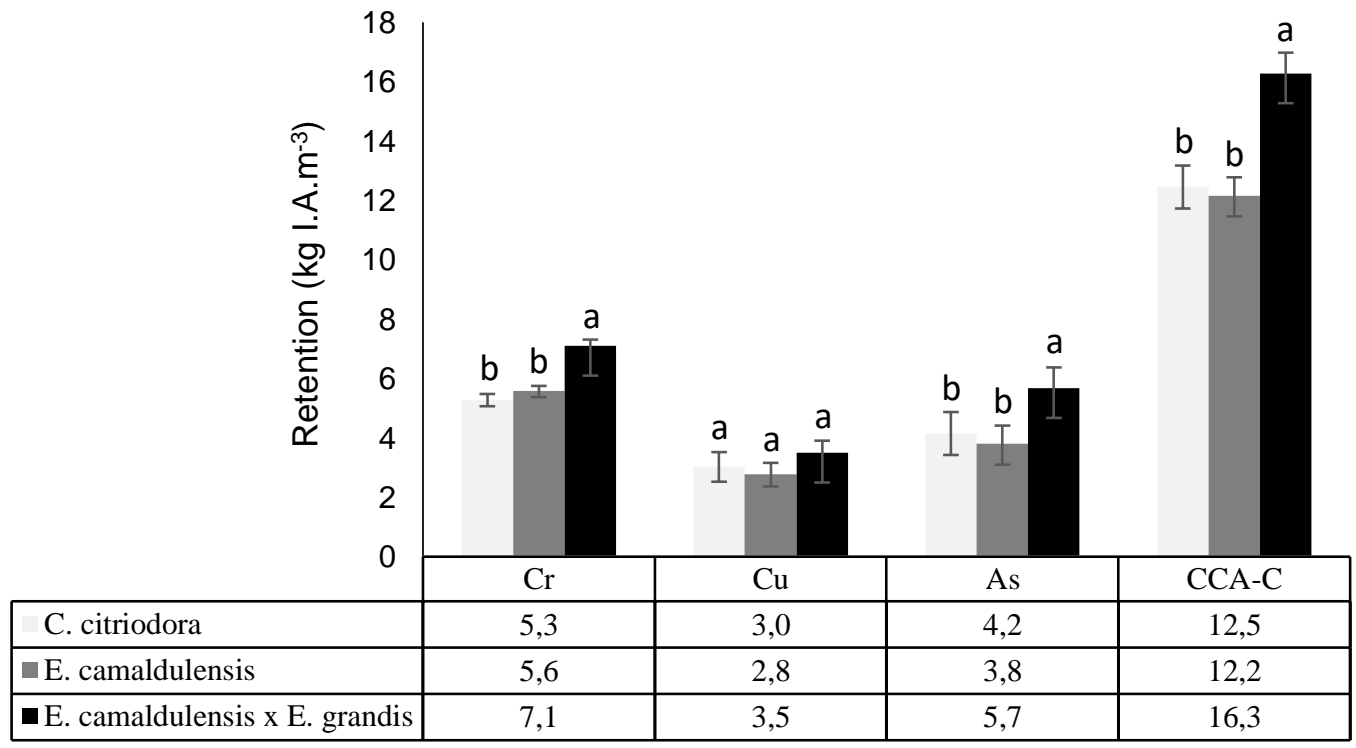

FLORESTA, Curitiba, PR, v. 51, n. 2, p. 410-418, abril/jun 2021.

Quintilhan, M. T. et.al.

ISSN eletrônico 1982-4688

DOI: $10.5380 /$ rf.v51 i2. 69280 
Figure 3. Mean retention values of $\mathrm{CrO}_{3}, \mathrm{CuO}, \mathrm{As}_{2} \mathrm{O}_{5}$ and CCA-C in kg.m ${ }^{-3}$, for the genetic materials evaluated. Bars for each compound followed by the same letter, do not differ statistically from each other (Tukey's test, $\mathrm{p}<0.05)$. Vertical lines indicating the standard deviation.

Figure 3. Valores médios da retenção de $\mathrm{CrO}_{3}, \mathrm{CuO}, \mathrm{As}_{2} \mathrm{O}_{5}$ e CCA-C em kg.m ${ }^{-3}$, para os materiais genéticos avaliados. Barras para cada composto, seguidas pela mesma letra, não diferem estatisticamente entre si (teste de Tukey, $\mathrm{p}<0.05$ ). Linhas verticais indicando o desvio padrão.

\section{Relating wood properties and preservative treatment quality}

The correlation coefficient between CCA retention, wood properties, and qualitative preservation parameters are described in Table 2. The correlation generated by all clones $(\Sigma)$ showed two strong negative correlations caused by diameter and the density $(\mathrm{p}<0.01)$. That is, the larger the diameter and higher the basic density of the genetic material, the lower the CCA retention in the wood.

For each clone individually, however, significant correlations changed (Table 2). C. citriodora did not correlate significantly with any of the wood properties or preservation parameters. However, E. camaldulensis, showed a strong correlation $(\mathrm{p}<0.01)$ between the retention of CCA in its wood and four wood properties: percentages of heartwood (-) and sapwood (+), heartwood/sapwood ratio (-) and basic density (-). For E. grandis $\mathrm{x}$ E. camaldulensis a significant correlation was observed with the diameter $(-)$ and the density $(-)(\mathrm{p}<0.05)$.

Table 2. Pearson's correlation of the wood properties and the qualitative parameters of the preservation, with the $\mathrm{CCA}-\mathrm{C}$ retention, for the three genetic materials

Tabela 2. Correlação de Pearson das propriedades da madeira e os parâmetros qualitativos da preservação, com a retenção de CCA-C, para os três materiais genéticos.

\begin{tabular}{ccccc}
\hline Parameters & C. citriodora & E. camaldulensis & $\begin{array}{c}\text { E. camaldulensis } \\
\text { grandis }\end{array}$ & $\Sigma$ \\
\hline Diameter $(\mathrm{cm})(-)$ & $\mathrm{ns}$ & $\mathrm{ns}$ & $*$ & $* *$ \\
\% Sapwood (+) & $\mathrm{ns}$ & $* *$ & $\mathrm{~ns}$ & $\mathrm{~ns}$ \\
$\%$ Untreated area (-) & $\mathrm{ns}$ & $\mathrm{ns}$ & $\mathrm{ns}$ & $\mathrm{ns}$ \\
$\%$ Heartwood (-) & $\mathrm{ns}$ & $* *$ & $\mathrm{~ns}$ & $\mathrm{~ns}$ \\
$\%$ Treated area (+) & $\mathrm{ns}$ & $\mathrm{ns}$ & $\mathrm{ns}$ & $\mathrm{ns}$ \\
H/S (+) & $\mathrm{ns}$ & $* *$ & $\mathrm{~ns}$ & $\mathrm{~ns}$ \\
Density $\left(\mathrm{g} \cdot \mathrm{cm}^{-3}\right)(-)$ & $\mathrm{ns}$ & $* *$ & $*$ & $* *$ \\
\hline
\end{tabular}

Where: $\mathrm{ns}=$ not significant $(\mathrm{p}<0.05)$; significant $(\mathrm{p}<0.05) ; * *$ significant $(\mathrm{p}<0.01) ;(+)$ positive correlation; $(-)$ negative correlation.

\section{DISCUSSION}

\section{Properties of wood and preservative treatment quality}

As presented in Table 1, the diameter values diverged among the genetic materials. The highest value was found in the E. camaldulensis $\mathrm{x}$ E. grandis hybrid. This was probably due to the greater adaptability and production of Eucalyptus multispecies hybrids in relation to the no/little crossed (SANTOS et al., 2013), thus explaining the lower $C$. citriodora and E. camaldulensis growth compared to the hybrid.

The diameter values for all genetic material met the requirements of NBR 9480 (ABNT, 2009), in which the optimal values for making stakes are between $10-16 \mathrm{~cm}$. A minimum diameter value regulates the use of very young individuals, that may not have reached their optimum growth potential and which still show a small portion of heartwood, or even its absence (VALLE et al., 2013), directly influencing the quality of preservation and consumption of the preservative solution.

The sapwood connection with wood preservation is remarkable, since this wood has a higher permeability and is usually not obstructed by extractives, resins and other phenolic compounds (SILVA et al., 2010). It is, therefore, considered the treatable area of the wood, for more easily receiving the preservative solution. However, occasionally sapwood undergoes a tylose process that obstructs the vessels of wood and reduces the conduction of water (DE MICCO et al., 2016) also interfering in the wood preservation.

The partial treatment of sapwood is observed in the E. camaldulensis x E. grandis hybrid, in which a tylose point in the sapwood possibly occurred. The hybrid, although not presenting complete penetration in the sapwood, a requirement of NBR 9480, satisfactory fulfills preservation recommendations, at least $10 \mathrm{~mm}$ thick (TORRES et al., 2011) and minimum retention of $6.5 \mathrm{~kg} . \mathrm{m}^{-3}$ of CCA (ABNT, 2009). The influence of the sapwood is remarkable in all evaluated clones, and the larger the sapwood area, the larger the treated area.

FLORESTA, Curitiba, PR, v. 51, n. 2, p. 410-418, abril/jun 2021. 
The penetration of the CCA in the wood of the genetic materials proved to be generally deep and homogeneous, except in the E. camaldulensis x E. grandis hybrid. The hybrid clone was precisely that with the largest diameter $(16.0 \mathrm{~cm})$, and even having the lowest density, it was the only one without full penetration of its sapwood (Table 1). This is probably due to the greater depth required that preservative must reach to fully penetrate the sapwood when compared to other genetic material, of reduced diameter. Further penetrations are directly related to smaller diameters (AMARAL et al., 2014; LOPES et al., 2017).

The heartwood is responsible for the natural durability of wood, which is highly obstructed by extractives, resins, tyloses, gums and other phenolic compounds, and is difficult to preserved due to its high impermeability (SILVA et al. 2010). Even with low permeability, it may be partially preserved. This is the case of $C$. citriodora and E. camaldulensis, which presented partial preservation of the heartwood area. Even difficult to preserve, the heartwood of some eucalyptus species can be treated (VALLE et al., 2013).

The heartwood, even presenting greater durability than the sapwood, is still not very durable when the tree is young (TORRES et al., 2011), being so desirable, a smaller portion of this wood intended for preservation. Consequently, there will be a larger treatable area, due to a higher proportion of sapwood (LOPES et al., 2017), enabling the generation of a higher quality product, as noted in $C$. citriodora, which presented a wide sapwood portion, and naturally a larger treated area.

Lower heartwood/sapwood ratio values have larger amount of sapwood directly and therefore the most treatable area, interfering in wood preservation. The relationship between heartwood and sapwood percentages affect wood drying, its permeability and possible uses. If the wood cracks during the drying process, it may generate a greater penetration of CCA during the preservative treatment, even superficially in the heartwood region (LOPES et al., 2017). However, at the same time, it may expose its untreated region from the heartwood to xylophagous organisms, yielding a lower quality product with less durability, and visually undesirable.

\section{Relating wood properties and preservative treatment quality}

For all genetic materials there was a negative relationship between the density and the wood diameter (Table 1). That is, the higher the developing diameter, the lower the density relation common to several species, including the eucalyptus (SANTOS et al., 2013). Woods with high density generally have low porosity and permeability, characteristics that negatively influence the preservation of wood since they are difficult to penetrate (LIMA et al., 2014). Nevertheless, a higher density without extensive obstruction of the vessel lumen, as is the usual case of sapwood, provides good preservative penetration and retention, as observed in the clones evaluated.

The CCA solution is the most used preservative worldwide due to its ease of industrial production, such as low cost, large volume of treated wood and high increase of wood durability (VIDAL et al., 2015). This is achieved by the balance among its components, each with an important role in increasing the long-term durability of the wood. For wood treated with CCA, higher arsenic retention values are common (SCHNEID et al., 2013). This compound has, as its main benefit, high toxicity to various insects and fungi, including those that exhibit tolerance to the presence of copper, which also acts as a fungicide (VIDAL et al., 2015). Chromium serves as a fixation agent for arsenic and copper, avoiding the leaching of both (RADIVOJEVIC; COOPER, 2010).

The preservative retention by all clones $(\Sigma)$, even with significant correlation with the wood density and the diameter of the clones, showed more of an influence by density (Table 2). This is noteworthy when observing E. camaldulensis $\mathrm{x}$ E. grandis, because even with the largest diameter (Table 1), the hybrid was the material with the highest CCA retention in its wood, standing out to the other clones (Figure 3).

The density was the property with the highest negative correlation to CCA retention and thus, wood preservation quality. Lima et al. (2014), evaluating different eucalyptus species, obtained lower CCA retention in dense woods. Precisely the genetic material that has lower density (E. grandis x E. camaldulensis) reached the highest CCA retention levels. Nevertheless, when evaluating the penetration of the CCA and wood density, there was a positive relationship, contrary to CCA retention, as observed for $C$. citriodora and the other genetic materials (Table 1).

This contradiction between the density ratio and the penetration and retention of CCA may be explained by the density of sapwood and heartwood, which were evaluated together. As the density of the wood was evaluated without distinction between these two regions, the relationship of this property with the penetration and retention was contrary. Sales-Campos et al. (2001) show the influence of different properties of the heartwood and sapwood on wood preservation. By determining the specific density of each region (heartwood and sapwood), a negative relationship between CCA density and penetration would probably be established, since preservation is strongly influenced by the heartwood and sapwood characteristics.

\section{Reduction of log length and moisture: higher CCA retention}

The preservation quality of the present study was influenced by two other important properties, moisture and length of short logs. Lopes et al. (2017) argue that CCA retention in wood is also influenced by moisture and the log length. The retention values obtained for the three genetic materials of the present study were higher than

FLORESTA, Curitiba, PR, v. 51, n. 2, p. 410-418, abri1/jun 2021.

Quintilhan, M. T. et.al.

ISSN eletrônico 1982-4688

DOI: $10.5380 /$ rf.v51 i2. 69280 
those found in several studies, which also treated eucalyptus logs under similar conditions (Table 3). Even with different moisture values, the main variation occurred in the length of the evaluated small logs.

The use of reduced length logs for autoclaving, allows greater retention of the solution, due to the increased contact surface between the timber and the preservative. This, combined with the low moisture content of the wood $(\sim 12 \%)$ allowed a high retention of the solution. In situations in which high length logs are not necessary, we recommend the preservation of shorter and low moisture logs. This change becomes a good option, especially in cases where the wood presents less permeability. Changes such as increased pressure and its duration in the preservation process could be replaced by reducing the logs length and moisture, thus reducing costs and obtaining better CCA penetration and retention values in the wood.

Tabela 3. Length (m), moisture $(\%)$ and mean CCA retention $\left(\mathrm{kg} \cdot \mathrm{m}^{-3}\right)$ of autoclave-treated Eucalyptus logs, from different research conducted.

Table 3. Comprimento $(\mathrm{m})$, umidade $(\%)$ e retenção média de CCA $\left(\mathrm{kg} \cdot \mathrm{m}^{-3}\right)$ dos toretes de eucalipto tratados em autoclave, de diferentes pesquisas realizadas.

\begin{tabular}{cccc}
\hline Research & Length $(\mathrm{m})$ & Moisture $(\%)$ & Retention $\left(\mathrm{kg} . \mathrm{m}^{3}\right)$ \\
\hline Schneid et al. $(2013)$ & 12.0 & $<30$ & 8.59 \\
Valle et al. $(2013)$ & 3.0 & $<30$ & 8.50 \\
Amaral et al. $(2014)$ & 2.30 & 26.99 & 6.67 \\
Paes et al. $(2012)$ & 2.20 & $<30$ & 8.12 \\
Lopes et al. $(2017)$ & 2.20 & $15-20$ & 8.23 \\
Arantes et al. $(2017)$ & 1.60 & 28.84 & 6.23 \\
\hline Present study & $\mathbf{0 . 4 0}$ & $\sim \mathbf{1 2}$ & $\mathbf{1 3 . 6 6}$ \\
\hline
\end{tabular}

\section{CONCLUSIONS}

- The three evaluated genetic materials showed to be suitable for use as preserved fence posts, as there was wide penetration and CCA retention in their woods. Among the clones, Corymbia citriodora presented the best preservation characteristics, with high CCA retention and deep penetration, completely in the sapwood and partial in the heartwood.

- Of the evaluated wood properties, those that presented the highest correlation with CCA retention for all evaluated genetic materials, were the diameter and the density of the wood, with negative relation. Other properties as percentage of sapwood and heartwood were highly correlated, however, only for Eucalyptus camaldulensis.

- Shorter length of logs associated with low moisture, proved to be highly influential in increasing CCA retention in wood, as compared to other studies. In difficult wood preservation situations, where the length of the logs is not a limiting factor, the use of short logs has potential as treated wood with higher retention and lower cost.

\section{ACKNOWLEDGEMENTS}

The authors thank the Conselho Nacional de Desenvolvimento Científico e Tecnológico - CNPq and the Eucalipto Tratado Santo André company for their support for the development of this work.

\section{REFERENCES}

AMARAL, L. S.; SILVA, J. R. M.; HEIN, P. R. G.; TRUGILHO, P. F. Influência do diâmetro e umidade no tratamento preservativo de moirões de Eucalyptus. Revista Árvore, Viçosa, v. 38, n. 5, p. 919 - 925, 2014.

ARANTES, L. S.; HEIN, P. R. G.; SILVA, J. R. M. DA; SOARES, V. C. Influência do tratamento preservativo com CCA-C na estabilidade dimensional da madeira de Eucalyptus. Scientia Forestalis, Piracicaba, v. 45, n. 114, p. 285 - 293, 2017.

ASSOCIAÇÃO BRASILEIRA DE NORMAS TÉCNICAS. NBR 11941: Madeira - Determinação da densidade básica. Rio de Janeiro, 2003.

ASSOCIAÇÃO BRASILEIRA DE NORMAS TÉCNICAS. NBR 6232: Penetração e retenção de preservativos em madeira tratada sob pressão. Rio de Janeiro, 2013.

FLORESTA, Curitiba, PR, v. 51, n. 2, p. 410-418, abril/jun 2021. 
ASSOCIAÇÃO BRASILEIRA DE NORMAS TÉCNICAS. NBR 9480: Peças roliças preservadas de eucalipto para construções rurais - Requisitos. Rio de Janeiro, 2009.

BALDIN, T.; MARCHIORI, J. N. C.; TALGATTI, M. Anatomia da madeira de Eucalyptus benthamii Maiden \& Cambage, espécie promissora para o setor de celulose no sul do Brasil. Balduinia, Santa Maria, n. 59, p. 10 - 18, 2017.

BRASIL. Projeto Radam Brasil: folhas SE 21 - Corumbá e SD 21 - Chapada dos Guimarães; geomorfologia, pedologia, vegetação e uso potencial da terra. Departamento Nacional de Produção Mineral, Rio de Janeiro, 1982.

FERREIRA, D. H. A. A.; LELES, P. S. DOS S.; OLIVEIRA NETO, S. N.; PAULA, T. R.; COUTINHO, R. P.; SILVA, R. L. Crescimento e produção de eucalipto na Região do Médio Paraíba do Sul, RJ. Floresta e Ambiente, Seropédica, v. 24, n. 1, p. 1 - 9, 2017.

FOOD AND AGRICULTURE ORGANIZATION OF THE UNITED NATIONS (FAO). In State of the World's Forests. Available at: http://www.fao.org/docrep/007/y5574e/y5574e00.htm Acessed in: 18 july 2019.

INDUSTRIA BRASILEIRA DE ARVORES (IBÁ). Relatório IBÁ 2017. Available at: <http://iba.org/images/shared/Biblioteca/IBA_Rela torioAnual2016_.pdf>. Acessed in: 18 july 2019.

INSTITUTO BRASILEIRO DE GEOGRAFIA E ESTATÍSTICA - IBGE. Pesquisa Industrial Anual (PIAProduto) de 2016. Available at: 〈https://www.ibge.gov.br/estatisticas/economicas/industria/9044-pesquisaindustrial-anual-produto.html?t=destaques $>$. Acessed in: 18 july 2019.

LIMA, F. C. DE C.; SARTORI, M. S.; SEVERO, E. T. D.; CALONEGO, F. W. Tratamento de seis espécies de Eucalyptus spp., utilizando arseniato de cobre cromatado (CCA-C) em método industrial com autoclave. Revista Científica Eletrônica de Engenharia Florestal, Garça, v. 23, n. 1, p. 71 - 80, 2014.

LOPES, D. J. V.; PAES, J. B.; JANKOWSKY, I. P.; SEGUNDINHO, P. G. A.; VIDAURRE, G. B. Influências do diâmetro e umidade da madeira na qualidade do tratamento preservativo. Floresta e Ambiente, Seropédica, v. 24, p. 1 - 10, 2017.

OLIVEIRA, J. T. DA S.; HELLMEISTER, J. C.; TOMAZELLO FILHO, M. Variação do teor de umidade e da densidade básica na madeira de sete espécies de eucalipto. Revista Árvore, Viçosa, v. 29, n. 1, p. 115 - 127, 2005. PAES, J. B.; LOMBARDI, L. R.; OLIVEIRA, J. T. D. S.; SILVA, L. F.; SANTOS, L. L. Qualidade de moirões de eucalipto tratados comercializados em três Municípios do Espírito Santo. Floresta e Ambiente, Seropédica, v. 19, n. 4, p. 475 - 482, 2012.

PEREIRA, B. L. C.; OLIVEIRA, A. C.; CARVALHO, A. M. M. L.; CARNEIRO, A. C. O.; VITAL, B. R.; SANTOS, L. C. Correlações entre a relação cerne/alburno da madeira de eucalipto, rendimento e propriedades do carvão vegetal. Scientia Forestalis, v. 41, n. 98, p. 217 - 225, 2013.

QUINTILHAN, M. T.; OLIVEIRA, W. C.; OLIVEIRA, A. C.; PEREIRA, B. L. C.; MÔRA, R.; PINTO, A. A. S. Deterioração da madeira de Eucalyptus e Corymbia em ensaio de campo. Revista Ciência da Madeira, Pelotas, v. 9, n. 2, p. $82-94,2018$.

RADIVOJEVIC, S.; COOPER, P. A. The effects of wood species and treatment retention on kinetics of CCA-C fixation reactions. Wood Science and Technology, Germany, v. 44, n. 2, p. 269 - 282, 2010.

SALES-CAMPOS, C.; VIANEZ, B. F.; MENDONÇA, M. S. Estudo da variabilidade da retenção do preservante CCA tipo A na madeira de Brosimum rubescens Taub. Moraceae - (Pau-rainha) uma espécie madeireira da região amazônica. Revista Árvore, Viçosa, v. 27, n. 6, p. 845 - 853, 2003.

SANTOS, G. A.; RESENDE, M. D. V.; SILVA, L. D.; HIGA, A.; ASSIS, T. F. Adaptabilidade de híbridos multiespécies de Eucalyptus ao Estado do Rio Grande do Sul. Revista Árvore, Viçosa, v. 37, n. 4, p. 759 - 769, 2013.

SCHNEID, E.; GATTO, D. A.; CADEMARTORI, P. H. G. Evaluation of the treatment with CCA-C under pressure on Eucalyptus saligna and Eucalyptus cloeziana wood poles. Scientia Forestalis, Piracicaba, v. 41, n. 100, p. $541-547,2013$.

SILVA, M. R.; MACHADO, G. O.; DEINER, J.; CALIL JUNIOR, C. Permeability measuremens of brazilian Eucalyptus. Materials Research, São Carlos, v. 13, n. 3, p. 281 - 286, 2010.

TORRES, P. M. A.; PAES, J. B.; LIRA FILHO, J. A.; NASCIMENTO, J. W. B. Tratamento preservativo da madeira juvenil de Eucalyptus camaldulensis Dehnh: pelo método de substituição de seiva. Cerne, Lavras, v. 17, n. 2, p. $275-282,2011$.

VALLE, M. L. A.; SILVA, J. DE C.; LUCIA, R. M. DELLA; EVANGELISTA, W. V. Retenção e penetração de CCA em madeira de primeira e segunda rotação de Eucalyptus urophylla S.T. Blake. Ciencia Florestal, Santa Maria, v. 23, n. 2, p. 481 - 490, 2013.

VIDAL, J. M.; EVANGELISTA, W. V.; SILVA, J. D. C.; JANKOWSKY, I. P. Preservação de madeiras no Brasil: histórico, cenário atual e tendências. Ciência Florestal, Santa Maria, v. 25, n. 1, p. 257 - 271, 2015.

FLORESTA, Curitiba, PR, v. 51, n. 2, p. 410-418, abril/jun 2021.

Quintilhan, M. T. et.al.

ISSN eletrônico 1982-4688

DOI: $10.5380 /$ rf.v51 i2. 69280 